EDITORIAL

\title{
A CONTABILIDADE E A ORDEM SOCIAL
}

Sob o enfoque puramente econômico, considera-se que o papel principal da contabilidade é fornecer um conjunto de informações que possam agregar valor a decisões de caráter econômico-financeiro. Entretanto, com o fortalecimento das democracias e o advento de novas tecnologias da informação, a contabilidade tradicional, voltada essencialmente para os acionistas, vem sendo mais desafiada a contemplar interesses de outros agentes, tais como sindicatos, associações comunitárias, entidades de defesa ambiental, universidades e agremiações políticas. Nesse particular, parte-se do princípio de que a empresa, como sistema aberto, deve ser compelida ou pelo menos estimulada a prestar contas sobre a sua atuação, especialmente no que se refere a consumo de recursos naturais, desenvolvimento de recursos humanos, contribuições ao governo, relacionamento com clientes e fornecedores, critérios que orientam a distribuição da riqueza por ela gerada, entre outros. Tudo isso alimenta a idéia de que a contabilidade não pode se limitar a prestar apoio à maximização da riqueza, mas deve colaborar também na construção e manutenção da ordem social.

Assim, parece ser correto afirmar que a visão microeconômica da contabilidade realmente não chega a contemplar todos os efeitos que as organizações empresariais exercem na sociedade. Além de fornecer dados relacionados com o desempenho econômico-financeiro, a empresa precisa assumir a obrigação de prover informações de interesse social, tais como custo da poluição ambiental, insalubridade, oferta de postos de trabalho, volume de demissões, contribuições ao erário público e outras do gênero. Nesse sentido, a contabilidade orientada para satisfazer interesses de acionistas não é mais do que um subconjunto da chamada contabilidade social, que busca alcançar interesses de um leque mais amplo de indivíduos. Parte-se do entendimento de que o acionista não é o único destinatário dos resultados das empresas e que a própria continuidade dos negócios não depende apenas dessa categoria de usuários das informações contábeis.

Como se pode deduzir, essa abordagem presume a existência de valores sociais estabelecidos que possam ser utilizados como parâmetro na determinação das práticas contábeis. A contabilidade passa, então, a ser julgada em função da contribuição que seus relatórios possam proporcionar à sociedade em sentido mais amplo e não a esta ou àquela categoria de usuário, em particular. De fato, se cada componente da sociedade, de uma forma ou de outra, é afetado pelas atividades empresariais, parece-nos inteiramente defensável a idéia de que pelo menos as empresas de maior porte deveriam ser obrigadas a publicar informações de cunho social, já que suas políticas tendem a promover maior impacto sobre a vida dos indivíduos. Pelo menos sob esse aspecto, ao elevar a DVA-Demonstração do Valor Adicionado à categoria de relatório obrigatório para determinados tipos de empresa, a legislação societária alcançou avanço digno de louvor. Acreditamos que essa peça contábil poderá contribuir para desenvolver e consolidar uma cultura empresarial que privilegie a transparência e permita à sociedade conhecer e valorizar esforços tendentes a conciliar sucesso econômico com responsabilidade social.

Para atuar como instrumento de construção e manutenção da ordem social, a contabilidade tende a se deslocar cada vez mais do plano puramente financeiro para contemplar um maior número de eventos e se ajustar às expectativas do conjunto da sociedade. Em todo o planeta, a crescente divulgação voluntária de informações de caráter social e ambiental expressa claramente esta tendência. No Brasil, por exemplo, cerca de $60 \%$ das sociedades anônimas que se enquadram no chamado novo mercado utilizam critérios sociais para qualificação, seleção e monitoramento de seus fornecedores de bens e serviços. 
Boa parte dessas empresas já está avaliando o impacto da incorporação de aspectos socioambientais em seus resultados financeiros. Tais iniciativas partem do princípio de que o progresso tecnológico e o lucro não asseguram a construção de uma sociedade justa e sustentável em longo prazo. De igual forma, baseia-se na premissa de que as condições físicas do planeta não suportam o enorme impacto de um crescimento econômico desordenado. Isso significa também que a lógica do lucro deve encontrar na função social da propriedade uma linha delimitadora.

Uma dos meios que a contabilidade já vem utilizando para ajudar a promover a ordem social é o chamado Balanço Social, haja vista que nesse tipo de relatório a empresa abre-se ao diálogo com os diversos agentes que, direta ou indiretamente, contribuem para o sucesso dos negócios. De modo específico, o referido Balanço pode contribuir para estimular posturas éticas e transparentes no âmbito corporativo, divulgar a contribuição que a empresa presta ao desenvolvimento de pesquisas e tecnologias, subsidiar negociações com empregados, contribuir para democratizar as relações com o público interno e externo, fortalecer as bases de confiança e transparência entre a empresa e os stakeholders, permitir acompanhar a evolução do processo de responsabilidade social da empresa etc.

No que se refere às organizações públicas, observa-se que o ordenamento jurídico do país também põe em destaque o papel da Contabilidade como instrumento de apoio à construção da ordem social. Um dos exemplos mais recentes pode ser encontrado na Lei de Responsabilidade Fiscal. Ao tratar da transparência da gestão fiscal, essa lei estabelece que se dê ampla divulgação a instrumentos de evidenciação, tais como planos, orçamentos, leis de diretrizes orçamentárias, pareceres de prestações de contas, relatórios de gestão físcal etc. Quanto aos sistemas de informações contábeis, destaca-se a necessidade de a Administração Pública manter sistema de custos que permita a avaliação e o acompanhamento da gestão orçamentária, financeira e patrimonial. De igual modo, salienta-se a necessidade de divulgar com clareza todos os eventos de interesse contábil, principalmente os relacionados a compromissos assumidos junto a terceiros.

Como se observa, a Lei de Responsabilidade Fiscal contribui para consagrar o relacionamento entre o governo, o público e a informação contábil. Isso torna-se mais evidente quando se considera que a mesma determina, em seu artigo de $n^{\circ}$. 49, que as contas apresentadas pelo chefe do Poder Executivo deverão ficar disponíveis, durante todo o exercício, no respectivo Poder Legislativo e no órgão técnico responsável por sua elaboração, para consulta e apreciação pelos cidadãos e instituições da sociedade. Com isso, a sociedade é guindada à condição de usuário privilegiado das informações contábeis, e estas, por sua vez, assumem claramente o status de instrumento de cidadania.

Naturalmente, tudo isso deve exercer reflexos sobre conceitos e diretrizes que norteiam a produção das informações contábeis. Porém, como conhecimento de natureza social, não resta à contabilidade outra saída senão se ajustar para atender às novas demandas que deverão surgir no âmbito social. Afinal, como bem salientam alguns estudiosos, a política contábil de um país não pode ficar atrelada a interesses de grupos específicos, tais como investidores individuais, administradores e contadores. Destaca-se, inclusive, que por maior que seja a dificuldade de se admitir esse fato, a política contábil nacional deve levar em conta o bem-estar social em sentido mais amplo.

José Maria Dias Filho

Professor Doutor da Faculdade de Ciências Contábeis da UFBA 